\title{
Surveying in highly-modified landscapes to document the occurrence of threatened species: a study of the giant armadillo Priodontes maximus in central Brazil
}

\author{
Frederico G. Lemos, Alan N. Costa, Fernanda C. Azevedo \\ Carlos E. Fragoso, Mozart C. Freitas-Junior and Ednaldo C. Rocha
}

\begin{abstract}
Studies on threatened species in highly modified and unprotected landscapes are necessary for the development of appropriate conservation policies. This is particularly important for species with large home ranges, such as the giant armadillo Priodontes maximus, whose occurrence in anthropogenic landscapes is poorly known despite its categorization as Vulnerable on the IUCN Red List. We searched and surveyed for the giant armadillo within human-modified areas in central Brazil using direct and indirect methods across a wide region dominated by diverse farming environments and scattered remnants of natural vegetation. During a 14-year period (2003-2016), we located 54 records of the species, including three road-kills and two instances of poaching. Most of the occurrence points (83\%) were in native vegetation, with $17 \%$ in anthropogenic environments (pastures and roads). We confirmed the presence of the giant armadillo within a wide, intensely humanaltered region. These findings indicate that Cerrado and Atlantic Forest remnants in modified landscapes in central Brazil play an important role as refuges for this armadillo species. In addition to habitat loss, road-kills and poaching persist as threats to the giant armadillo. Conservation actions are necessary to minimize human impacts and facilitate the persistence of the giant armadillo in this region. Policies that both deter illegal deforestation and strengthen incentives for the protection of natural vegetation remnants and restoration of biological corridors such as gallery forests would aid conservation of the giant armadillo in this area.
\end{abstract}

Keywords Agro-ecosystems, biodiversity loss, Cingulata, extinction debt, fragmented landscapes, Neotropical habitat, Priodontes maximus, wildlife conservation

\footnotetext{
Frederico G. Lemos (Corresponding author) and Alan N. Costa Programa de Conservação Mamíferos do Cerrado, Unidade Acadêmica Especial de Biotecnologia, Universidade Federal de Goiás, Av. Lamartine P. Avelar 1120, Catalão, CEP 75704-020, Goiás, Brazil. E-mail lemos.pcmc@gmail.com

Fernanda C. Azevedo Programa de Conservação Mamíferos do Cerrado, Programa de Pós-graduação em Ecologia, Universidade Federal de Viçosa, Viçosa, Minas Gerais, Brazil

Carlos E. Fragoso and Mozart C. Freitas-Junior Programa de Conservação Mamíferos do Cerrado, Cumari, Goiás, Brazil

Ednaldo C. Rocha Universidade Estadual de Goiás, Ipameri, Goiás, Brazil

Received 31 March 2017. Revision requested 25 July 2017.

Accepted 24 November 2017. First published online 8 August 2018.
}

Supplementary material for this article is available at https://doi.org/10.1017/So030605317001867

\section{Introduction}

ata on the demography, ecological interactions and environmental requirements of Neotropical wildlife, and anthropogenic threats, have been used in the management of several species (e.g. Sanderson et al., 2002; Medici et al., 2007; ICMBio, 2015b). Although data accuracy and generality are paramount for conservation and management, most studies are context-dependent, concentrated either in regions dominated by pristine ecosystems or in medium to large protected areas (Fazey et al., 2005). For threatened species, however, studies across landscapes modified and managed by humans are fundamental for the development of appropriate conservation policies (Chazdon et al., 2009).

Armadillos (Cingulata: Dasypodidae) are limited to the Neotropics (Wetzel, 1985) and some species are sensitive to environmental change (Abba \& Superina, 2010). Of 11 species recorded in Brazil (ICMBio, 2015a), the giant armadillo Priodontes maximus is categorized as Vulnerable on the IUCN Red List (Anacleto et al., 2014). Populations of this armadillo are decreasing as a result of habitat loss, poaching, road-kills and the indiscriminate use of fire to remove natural vegetation or induce regrowth of pastures (Abba \& Superina, 2010; Martins et al., 2015). The lack of knowledge about the giant armadillo hinders the implementation of conservation actions, especially those focused on human-dominated landscapes (Meritt, 2006; Superina \& Abba, 2014). For example, although the predicted range of $P$. maximus extends from Venezuela to northern Argentina, including a large portion of Brazil (Anacleto et al., 2014; Chiarello et al., 2015), it encompasses broad regions without records, and the species has been considered extinct in areas with high levels of urbanization/agricultural activities or without official records (Chiarello et al., 2008; Srbek-Araujo et al., 2009). Despite its size (30-50 kg; Superina \& Abba, 2014) the giant armadillo is rarely observed because of its naturally low density and because it is nocturnal and fossorial (Noss et al., 2004; Silveira et al., 2009; Srbek-Araujo et al., 2009; Aya-Cuero et al., 2017). The absence of records of this species in highly modified 
areas could be a result of low survey effort rather than absence per se.

Central Brazil lies within the range of $P$. maximus (Anacleto et al., 2014; Chiarello et al., 2015) and is dominated by the Cerrado biome, with the Atlantic Forest biome represented by enclaves of seasonal forest along watercourses (e.g. the Paranaíba river basin; Ribeiro et al., 2009). As a result, there is a rich mosaic of physiognomies, ranging from open grasslands to forest patches, favouring a high regional biodiversity (Lopes et al., 2012). However, agricultural activities and urbanization have resulted in the replacement of $>50 \%$ of the natural vegetation by anthropogenic environments (Machado et al., 2004). The landscape now comprises a matrix of exotic pastures and crops surrounding fragments of natural vegetation, the latter located mainly on higher slopes or in rugged terrain (Klink \& Machado, 2005; Carvalho et al., 2009). The occurrence of P. maximus in central Brazil remains poorly known (Martins et al., 2015). Here, we present records of the giant armadillo in modified landscapes of the Cerrado biome and ecotone areas with the Atlantic Forest biome in the border area of the states of Goiás and Minas Gerais. We also present data on the species' activity period and its habitat use in agroecosystems.

\section{Study area}

Our study area lies in 10 municipalities of Goiás and Minas Gerais States (Supplementary Table 1; Fig. 1), in a region where $70-80 \%$ of the area is occupied by cattle ranches with exotic pastures, and the remainder comprises scattered natural patches of savannah (Cerrado) and mesophytic seasonal forest (Atlantic Forest). The regional climate is markedly seasonal (Alvares et al., 2013), with a mean annual temperature of $23-25^{\circ} \mathrm{C}$ and mean annual total precipitation of $1,600-1,900 \mathrm{~mm}$.

\section{Methods}

Data on P. maximus occurrence were obtained during 20032016 in natural vegetation remnants in farmlands, private reserves, and protected areas, from camera trapping (Plate 1a), sightings (Plate $1 \mathrm{~b}$ ), tracks (Plate $2 \mathrm{a}$ ) and fresh burrows (Plate $2 \mathrm{~b}$ ). We did not include old, abandoned burrows or those where there was evidence they had been used by other species (Desbiez \& Kluyber 2013). Camera-trap surveys were in private natural vegetation remnants in the municipalities of Araguari (Minas Gerais; 2009-2016), in pastures with dense bushes in Cumari (Goiás; 2003-2016), in the Serra de Caldas Novas State Park (Caldas Novas, Goiás; 2010-2011), and in the private reserve Pé do Morro Farm of the Universidade Federal de Goiás (Catalão, Goiás; 2014-2015). Camera-trap records in different months at each location were considered separately. To determine if camera-trap photographs were taken during the day or night we calculated the time of sunrise and sunset for the location and date of each photograph, using $R v .2 .6$ ( $\mathrm{R}$ Development Core Team, 2014). We also included data from road-kills (Plate 3 a) and poaching by local people, reported voluntarily during occasional visits to farms (Plate $3 \mathrm{~b}$ ). We compared our findings with those of previous studies (Martinelli et al., 2014; Araújo et al., 2015; Chiarello et al., 2015; Estrela et al., 2015; Gomes et al., 2015; Rocha et al., 2015; Fig. 1).

To determine habitat use we classified the vegetation in each location as savannah, forest or pasture. Savannah has a relative predominance of native grasses and scattered shrubs

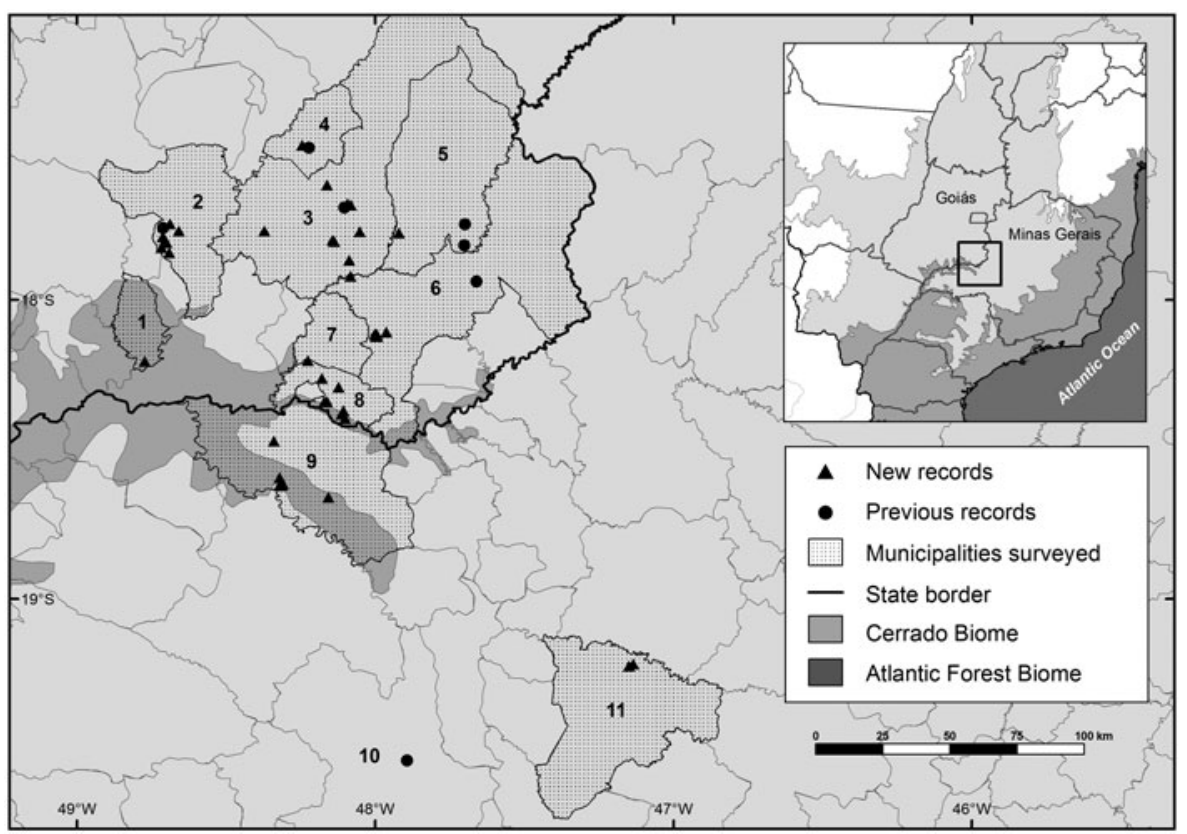

FIG. 1. Records of the giant armadillo Priodontes maximus in 10 municipalities in the states of Goiás and Minas Gerais, Brazil. Municipalities: 1, Água Limpa; 2, Caldas Novas; 3, Ipameri; 4, Urutaí; 5. Campo Alegre; 6, Catalão; 7 , Goiandira; 8, Cumari; 9, Araguari; 10, Uberaba; 11, Perdizes. Previous records are from Martinelli et al. (2014), Araújo et al. (2015), Chiarello et al. (2015), Estrela et al. (2015), Gomes et al. (2015), and Rocha et al. (2015). 

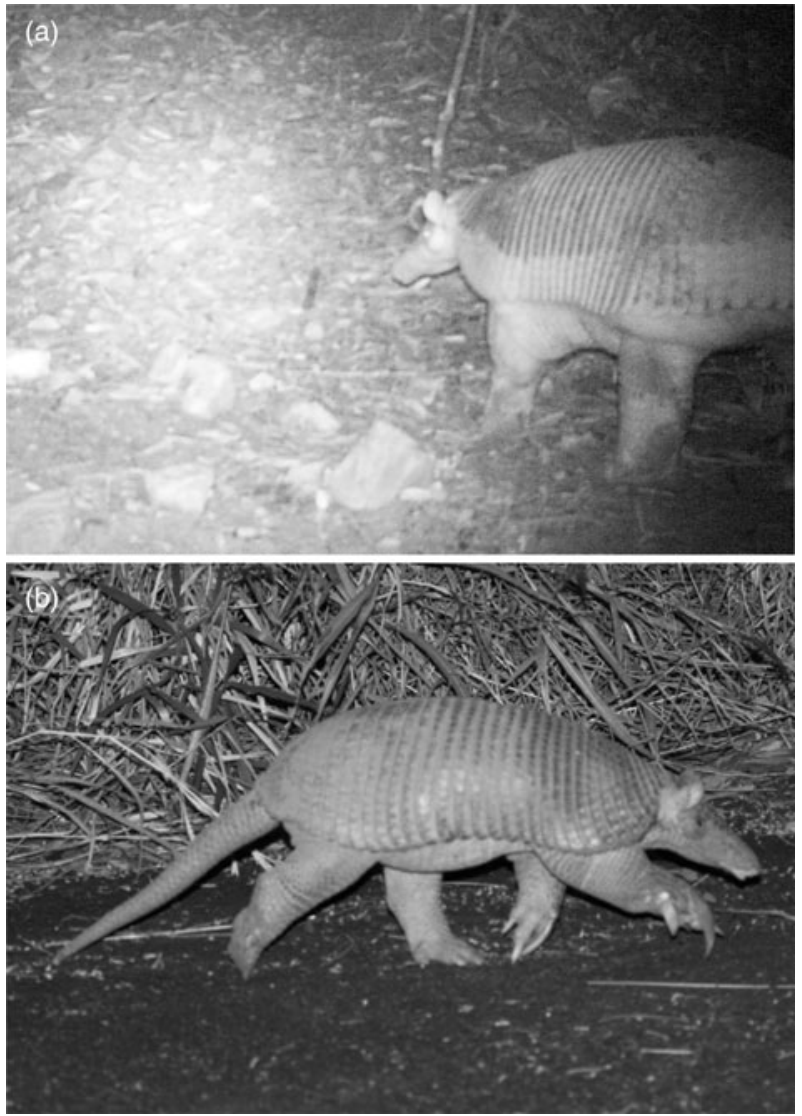

Plate 1. Giant armadillos Priodontes maximus recorded by (a) camera trapping and (b) sighting in Pé do Morro Farm reserve and Serra de Caldas Novas State Park (respectively), in the state of Goiás (Fig. 1).

and small trees, which in the Cerrado includes the vegetation physiognomies campo sujo, campo cerrado and cerrado sensu stricto. Forest consisted of trees $>12 \mathrm{~m}$ tall and with canopy formation such as the cerradão physiognomy,
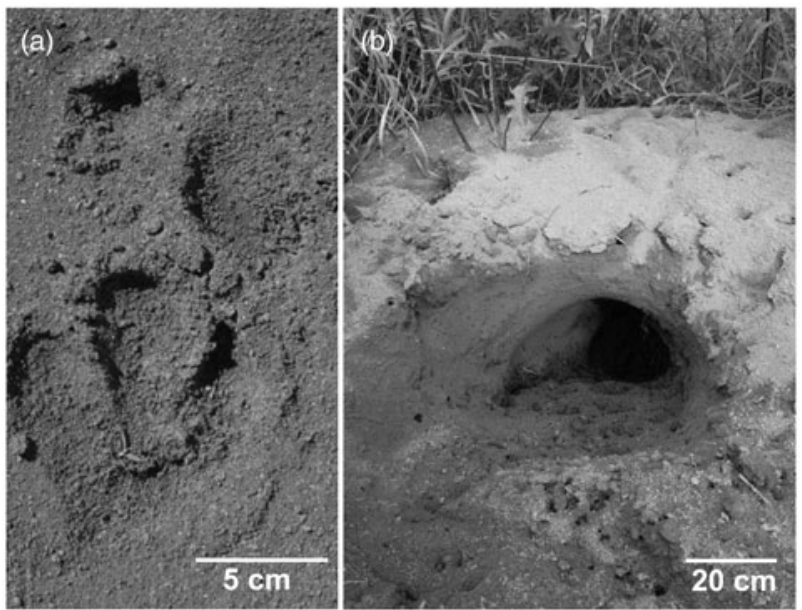

Plate 2. Typical evidence of the giant armadillo used to record the species: (a) track and (b) fresh burrow on a leaf-cutter ant nest.
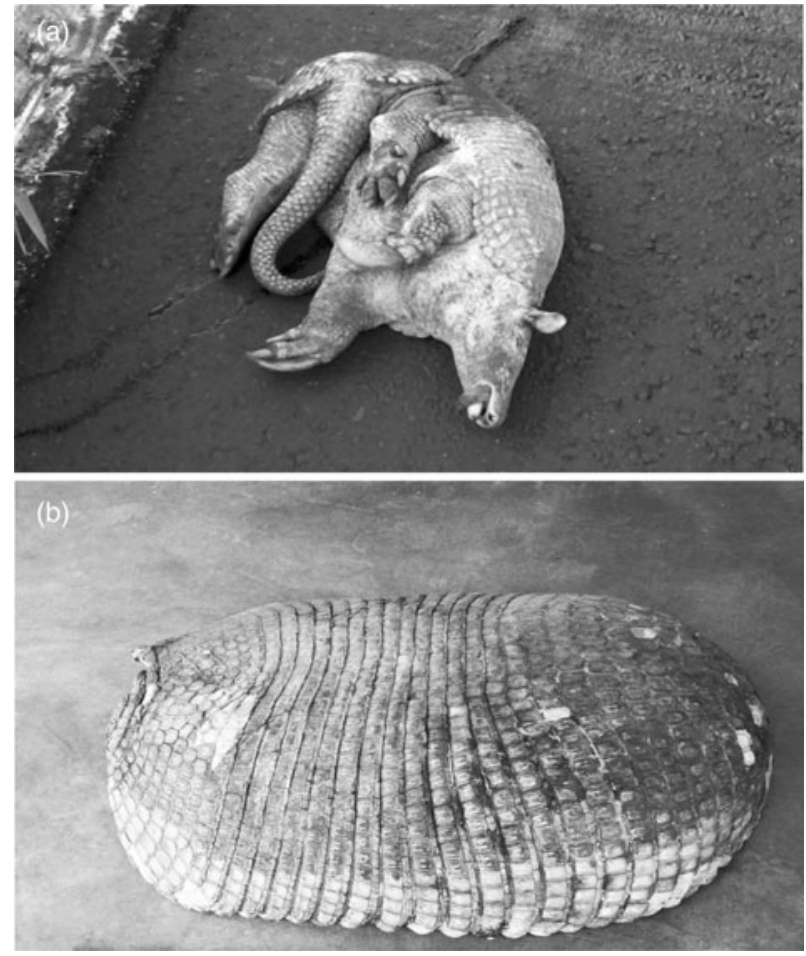

Plate 3. Carcasses of the giant armadillo recorded in the state of Goiás: (a) killed on the GO-33o highway, and (b) the carapace of a poached animal.

seasonal forests, riverine forests or gallery forests (Oliveira-Filho \& Ratter, 2002). To assess differences in proportions of used and available habitat we compared the frequency of records and available habitat for the agro-ecosystems surveyed in Araguari (Minas Gerais; F.C. Azevedo unpubl. data) and Cumari (Goiás; F.G. Lemos unpubl. data), and the reserve Pé do Morro Farn in Catalão (Goiás; Cardoso \& Moreno, 2013).

\section{Results}

During the 14-year period we obtained a total of 54 records of P. maximus: 27 from 16 private farmlands, 12 in a private reserve, 10 in three protected areas, three animals killed on paved roads and two poached (Fig. 1; Supplementary Table 1). Forty-six per cent of the records were from camera trapping (17), carcasses (5) and sightings (3), and 54\% (29) were from fresh burrows and tracks, often on trails or at the edge of dirt roads.

Camera-trap photographs and sightings were almost exclusively during the night (Fig. 2), with just one in daylight, shortly after dawn (Supplementary Table 1). Most records were in areas with native vegetation cover (83\%), with 24 in forest and 21 in savannah. In Cumari and Catalão six records were in pastures. The frequency of records in different habitats generally followed their relative availability in each study site (Table 1). The $17 \%$ of records in anthropogenic 


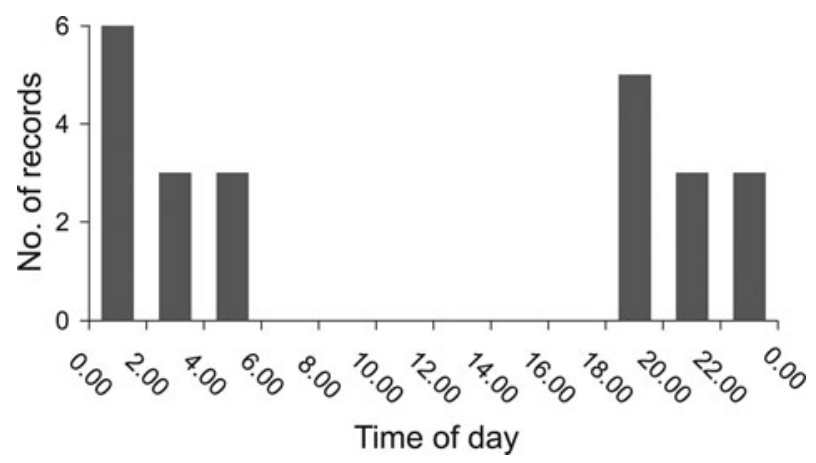

FIG. 2. Activity pattern of the giant armadillo, based on 20 camera-trap photographs and three sightings during July 2010October 2016 in four municipalities in the states of Goiás and Minas Gerais (Fig. 1).

environments, including road-kills, were $<0.45 \mathrm{~km}$ from natural vegetation remnants.

\section{Discussion}

The giant armadillo is widely distributed in central Brazil (Anacleto et al., 2014; Chiarello et al., 2015), and elderly rural residents reported to us that formerly it was not unusual to find this armadillo's tracks or to sight the species on their properties. However, the giant armadillo is now rarely seen, most likely as a result of habitat loss combined with road-kills and poaching (Chiarello et al., 2008). Intensive mammal surveys have only recently been conducted in natural vegetation remnants across the study region (Bruna et al., 2010; Araújo et al., 2015; Estrela et al., 2015; Gomes et al., 2015; Rocha et al., 2015). Our study spans the longest period (14 years) and covered $192 \mathrm{~km}^{2}$ of Cerrado and Atlantic Forest remnants.

Protected areas on the border of Minas Gerais and Espirito Santo states are considered the last stronghold for P. maximus in the Atlantic Forest (Srbek-Araujo et al., 2009) but our findings indicate that the species is still present in Atlantic Forest remnants within the basins of the Paranaíba and Araguari rivers. In addition, a record from Vale do Encantado Private Natural Heritage Reserve in the municipality of Uberaba (Minas Gerais) expands the southern range of the species (Martinelli et al., 2014; Fig. 1). Previous studies in south-east Goiás state located only six records of P. maximus for 2004-2014 (Araújo et al., 2015; Chiarello et al., 2015; Estrela et al., 2015; Gomes et al., 2015), but we found 42 records within the same general area. Based on the home range size of a giant armadillo (500-1,500 ha; Silveira et al., 2009) we assume that at least one animal was living in the vegetation remnants surrounding the record points, and thus our findings, in combination with previous records, potentially indicate the persistence of several populations of this species in natural patches across a large section of agro-ecosystems in central Brazil. However, there are many potentially suitable vegetation remnants within the area that remain unsurveyed.

Our findings corroborate previously identified traits of giant armadillos: individuals are essentially nocturnal (Noss et al., 2004; Silveira et al., 2009; Srbek-Araujo et al., 2009; Aya-Cuero et al., 2017), occur in both open savannah and closed forest habitats, and their use of habitat tends to reflect habitat availability in the landscape (Silveira et al., 2009). It is most likely that giant armadillos select areas with populations of termites or ants, which are their main food items (Anacleto, 2007), independently of the dominant vegetation of an area.

Although we surveyed extensive areas of pasture in the matrix between natural vegetation patches, the low frequency of records (11\%) in this environment suggests that exploration of human-modified habitats is uncommon for giant armadillos even in predominantly altered landscapes; they mainly explore natural vegetation patches within these highly modified areas (Silveira et al., 2009). Similarly, the bush dog Speothos venaticus tends to use native vegetation preferentially ( $95 \%$ of records in savannah and forest patches), even where this vegetation occupied only one-third of a cultivated landscape in Mato Grosso state (Lima et al., 2015). This highlights the importance of the protection of private reserves and biological corridors, mainly gallery forests, for the conservation of rare and threatened species in modified landscapes.

Habitat fragmentation often results in vegetation patches decreasing in size and increasing in number and isolation

TABLE 1 Availability of habitats and number of records (from camera trapping, sightings, carcass recovery, tracks and burrows) of the giant armadillo Priodontes maximus during 2009-2016 in the municipalities of Araguari (Minas Gerais) and Cumari (Goiás), and the reserve Pé do Morro Farm in Catalão (Goiás).

\begin{tabular}{|c|c|c|c|c|c|c|}
\hline \multirow[b]{2}{*}{ Habitat } & \multicolumn{3}{|l|}{ Area, ha (\%) } & \multicolumn{3}{|c|}{ No. of records (\%) } \\
\hline & Araguari & Cumari & Pé do Morro Farm ${ }^{1}$ & Araguari & Cumari & Pé do Morro Farm \\
\hline Savannah & $396(0.4)$ & $2,104(4.4)$ & $38(42.0)$ & $1(10.0)$ & $1(12.5)$ & $4(33.3)$ \\
\hline Forest & 30,024 (31.9) & $10,033(21.1)$ & $31(34.0)$ & $9(90.0)$ & $4(50.0)$ & $5(41.7)$ \\
\hline Pastures \& crops & $56,065(59.6)$ & $34,945(73.6)$ & $21(24.0)$ & $0(0)$ & $3(37.5)$ & $3(25.0)$ \\
\hline Others $^{2}$ & $7,644(8.1)$ & $404(0.9)$ & $0(0)$ & $0(0)$ & $0(0)$ & $0(0)$ \\
\hline
\end{tabular}

${ }^{1}$ Data from Cardoso \& Moreno (2013).

${ }^{2}$ Urban areas, farm facilities, roads, artificial dams and degraded areas. 
(Fahrig, 2003), negatively affecting species with large spatial requirements such as the giant armadillo (Chiarello, 1999). However, 28 of our records were from fragments smaller (25-288 ha) than an armadillo's home range and therefore potentially unsuitable to support even a single giant armadillo. This could be explained by an extinction debt (Kuussaari et al., 2009) for the giant armadillo. The species' relatively long life expectancy (12-15 years; Nowak, 1999) indicates low population turnover and may mask the longterm effects of fragmentation. The irregular topography of the landscape in the border areas between Goiás and Minas Gerais states results in habitat remnants being close to each other, allowing giant armadillos to forage in small areas and still survive within fragmented landscapes for a limited time. This extinction delay could present an opportunity for recovery of this species via habitat restoration and landscape management (Kuussaari et al., 2009).

Road-kills of armadillos and other mammal species have been recorded in central Brazil (Fischer et al., 2003), and we located three road-kills, but this problem is probably underreported. Illegal hunting is still a common practice in central Brazil and game meat consumption remains a cultural habit, mainly in rural communities (FGL pers. comm.), although probably insignificant compared to that observed in the Amazon forest (e.g. Baía-Junior et al., 2010; van Vliet et al., 2014). The low frequency of hunting in agricultural regions (Rushton et al., 2005) such as central Brazil may be associated with access to domestic sources of animal protein and stricter environmental laws. We recorded only two poached giant armadillos, and suspect that hunting of this species in central Brazil is opportunistic.

The decline of the giant armadillo (at least 30\% since 1991; ICMBio 2015a) may influence community diversity and vegetation structure. The species is an ecosystem engineer (Leite-Pitman et al., 2004; Desbiez \& Kluyber, 2013; Aya-Cuero et al., 2017), a potential prey for large predators such as the jaguar Panthera onca and cougar Puma concolor, and a specialized insect-predator (Anacleto, 2007). With respect to the latter, the absence of a top-down effect on insect herbivores, especially leaf-cutter ants (Costa \& Vieira-Neto, 2016), may affect vegetation structure and dynamics in modified environments (Terborgh et al., 2001; Silva et al., 2012). The border region of the states of Goiás and West Minas Gerais has experienced intensive landscape modification, and $<2-3 \%$ of natural vegetation remnants lie within protected areas (Carvalho et al., 2009). The high degree of landscape modification and the high cost of land in this region are challenges to the establishment of protected areas large enough to ensure the conservation of large mammals. Changes in 2011 and 2012 to the Brazilian Forest Act, providing amnesty for illegal logging, allowing mandatory legal reserve areas to include sites previously prohibited from being deforested, and reducing the deforestation-free zone beside rivers, contribute to the decrease of biological connections between natural vegetation remnants and potentially result in biodiversity loss (Michalski et al., 2010; Paul et al., 2010).

Our research suggests that the giant armadillo may still occur in other highly modified areas of central Brazil and elsewhere, undetected because of low survey efforts. This may also be the case for other rare and threatened Brazilian species (e.g. bush dogs were recently recorded in our study area, where the species was expected but had not previously been observed; Azevedo et al., 2016). Our results suggest that road-kills and poaching, in addition to habitat loss, continue to threaten the giant armadillo in central Brazil. Policies that both deter illegal deforestation and strengthen incentives for the protection of natural vegetation remnants and restoration of biological corridors such as gallery forests are therefore necessary for the conservation of the giant armadillo in this area.

Acknowledgements We thank Hugo Costa, Frederico Cigano Souza, Leandro Abade, Guilherme Dias, Lucas Ribeiro and Tiago Borges for their assistance with fieldwork, Daniel Rocha for helping with time calculations, Leonardo Gomes for providing coordinates for mapping literature records, Stacie Castelda-Bickley, Arnaud Desbiez, Ernane Vieira-Neto, Martin Fisher and anonymous reviewers for their critiques, landowners and protected area managers for their hospitality, Capim Branco Energy Company for financial support for part of the study and Minas Gerais Electrical Company for the permit to work at Galheiro Private Natural Heritage Reserve. FCA was supported by a doctoral fellowship from HIDROEX (UNESCO/BID), and ECR by a grant from Goiás State University (PROBIP/PrP 009/2016).

Author contributions Conception and design of the study: FGL, ANC, FCA, CEF and ECR; data collection: FGL, ANC, FCA, CEF, MCF and ECR; writing: FGL, ANC, FCA and CEF; revisions: FGL, ANC, FCA, CEF, MCF and ECR

\section{Conflicts of interest None.}

Ethical standards This study abided by the Oryx Code of Conduct.

\section{References}

A вbа, A.M. \& Superina, M. (2010) The 2009/2010 Armadillo Red List Assessment. Edentata, 11, 135-184.

Alvares, C.A., Stape, J.L., Sentelhas, P.C., Gonçalves, J.L.M. \& Sparovek, G. (2013) Köppen's climate classification map for Brazil. Meteorologische Zeitschrift, 22, 711-728.

Anacleto, T.C.S. (2007) Food habits of four armadillo species in the Cerrado area, Mato Grosso, Brazil. Zoological Studies, 46, 529-537. Anacleto, T.C.S., Miranda, F., Medri, I., Cuellar, E., Abba, A.M. \& Superina, M. (2014) Priodontes maximus. In The IUCN Red List of Threatened Species: e.T18144A47442343. Http://dx.doi.org/10.2305/ IUCN.UK.2014-1.RLTS.T18144A47442343.en [accessed 4 May 2018]. Araújo, G.R., Silva, P.M., Estrela, D.C. \& Castro, A.L.S. (2015) Mamíferos de médio e grande porte em um fragmento florestal de Cerrado no município de Ipameri-GO. Multi-Science Journal, 1 , $55-61$. 
Aya-Cuero, C., Rodríguez-Bolaños, A. \& Superina, M. (2017) Population density, activity patterns, and ecological importance of giant armadillos (Priodontes maximus) in Colombia. Journal of Mammalogy, 98, 770-778.

Azevedo, F.C., Lemos, F.G., Rocha, D.G., Costa, A.N. \& de Freitas-Junior, M.C. (2016) New-record of the bush dog Speothos venaticus in a human-altered landscape in the west of Minas Gerais, Brazil. Bioscience Journal, 32, 1324-1330.

Baía-Junior, P.C., Guimarães, D.A. \& Le Pendu, Y. (2010) Non-legalized commerce in game meat in the Brazilian Amazon: a case study. Revista de Biologia Tropical, 58, 1079-1088.

Bruna, E.M., Guimarães, J.F., Lopes, C.T., Duarte, P., Gomes, A. C.L., Belentani, S.C.S. et al. (2010) Mammalia, Estação Ecológica do Panga, a Cerrado protected area in Minas Gerais state, Brazil. Check List, 6, 668-675.

Cardoso, E. \& Moreno, M.I.C. (2013) Considerações sobre aspectos da vegetação na Fazenda Pé do Morro, da Universidade Federal de Goiás, Campus Catalão. Brazilian Geographical Journal, 4, 169-180.

Carvalho, F.M.V., Marco-Júnior, P. \& Ferreira, L.G. (2009) The Cerrado into-pieces: habitat fragmentation as a function of landscape use in the savannas of central Brazil. Biological Conservation, 142, 1329-1403.

Chazdon, R.L., Harvey, C.A., Komar, O., Griffith, D.M., Ferguson, B.G., Martínez-ramos, M. et al. (2009) Beyond reserves: a research agenda for conserving biodiversity in human-modified tropical landscapes. Biotropica, 41, 142-153.

Chiarello, A.G. (1999) Effects of fragmentation of the Atlantic forest on mammal communities in south-eastern Brazil. Biological Conservation, 89, 71-82.

Chiarello, A.G., Aguiar, L.M.S., Cerqueira, R., Melo, F.R., Rodrigues, F.H.G. \& Silva, V.M.F. (2008) Mamíferos. In Livro vermelho da fauna brasileira ameaçada de extinção (eds A.B.M. Machado, G.M. Drummond \& A.P. Paglia), pp. 68o-88o. MMA/ Biodiversitas, Brasília, Brazil.

Chiarello, A.G., Röhe, F., Miranda, F.R., Mourão, G.M., Silva, K.F.M., Vaz, S.M. \& Anacleto, T.C.S. (2015) Avaliação de Risco de Extinção de Priodontes maximus (Kerr, 1792) no Brasil. Série Estado de Conservação da Fauna Brasileira, 2, 209-222.

Costa, A.N. \& Vieira-Neto, E.H.M. (2016) Species turnover regulates leaf-cutter ant densities in environmental gradients across the Brazilian Cerrado. Journal of Applied Entomology, 140, 474-478.

Desbiez, A.L.J. \& Kluyber, D. (2013) The role of giant armadillos (Priodontes maximus) as physical ecosystem engineers. Biotropica, 45, 537-540.

Estrela, D.C., Souza, D.C., Souza, J.M. \& Castro, A.L.S. (2015) Medium and large-sized mammals in a Cerrado area of the state of Goiás, Brazil. Check List, 11, 1-6.

FAHRIG, L. (2003) Effects of habitat fragmentation on biodiversity. Annual Review of Ecological and Environmental Systems, 34, 487-515.

Fazey, I., Fischer, J. \& Lindenmayer, D.B. (2005) What do conservation biologists publish? Biological Conservation, 124, $63-73$.

Fischer, W.A., Ramos-Neto, M.B., Silveira, L. \& Jácomo, A.T.A. (2003) Human transportation network as ecological barrier for wildlife on Brazilian Pantanal-Cerrado corridors. In Proceedings of the 2003 ICOET (eds C.L. Irwin, P. Garret \& K.P. McDermott), pp. 182-194. Center for Transportation and the Environment, North Carolina State University, Raleigh, USA.

Gomes, L.P., Rocha, C.R., Brandão, R.A. \& Marinho-Filho, J. (2015) Mammal richness and diversity in Serra do Facão region, Southeastern Goiás state, central Brazil. Biota Neotropica, 15, 1-11.

ICMBio (Instituto Chico Mendes de Conservação Da Biodiversidade) (2015a) Avaliação do risco de extinção dos
Xenartros Brasileiros. Instituto Chico Mendes de Conservação da Biodiversidade, Brasília, Brazil.

ICMBio (Instituto Chico Mendes de Conservação da Biodiversidade) (2015b) Sumário Executivo do Plano de Ação Nacional para a Conservação do Cachorro-vinagre. Instituto Chico Mendes de Conservação da Biodiversidade, Brazilia, Brazil.

Klink, C.A. \& MACHado, R.B. (2005) Conservation of the Brazilian Cerrado. Conservation Biology, 19, 707-713.

Kuussaari, M., Bommarco, R., Heikkinen, R.K., Helm, A., Krauss, J., Lindborg, R. et al. (2009) Extinction debt: a challenge for biodiversity conservation. Trends in Ecology \& Evolution, 24, 564-571.

Leite-Pitman, R., Powell, G., Cruz, D., Escobedo, M., Escobar, K., Vilca, V. \& MendozA, A. (2004) Habitat use and activity of the giant armadillo (Priodontes maximus): preliminary data from southeastern Peru. Conference paper. In Annual Meeting of the Society for Conservation Biology, pp. 1-8. Columbia University, New York, USA.

Lima, E.S., Jorge, M.L.S.P., Jorge, R.S.P. \& Morato, R.G. (2015) The bush dog Speothos venaticus: area requirement and habitat use in cultivated lands. Oryx, 49, 64-70.

Lopes, S.F., Schiavini, I., Oliveira, A.P. \& Vale, V.S. (2012) An ecological comparison of floristic composition in seasonal semideciduous forest in southeast Brazil: implications for conservation. International Journal of Forestry Research, 2012, 1-14.

Machado, R.B., Ramos-Neto, M.B., Pereira, P.G.P., Caldas, E.F., Gonçalves, D.A., SAntos, N.S. et al. (2004) Estimativas de perda da área do Cerrado brasileiro. Relatório Técnico. Conservation International, Brazilia, Brazil.

Martinelli, A.G., Costa, W.R., Neto, R.S., Fonseca, P.H.M., Martins, G. \& Silva, V.M. (2014) Priodontes Maximus (Cingulata, Dasypodidae) in the Reserva Particular do Patrimônio Natural Vale Encantado, Triângulo Mineiro, Southeastern Brazil. Acta Zoológica Mexicana, 30, 716-722.

Martins, A.B., Silva, K.F.M., De Fialho, M.S. \& Miranda, F.R. (2015) Avaliação do Estado de Conservação de Pilosa e Cingulata no Brasil. Série Estado de Conservação da Fauna Brasileira, 2, 7-11.

Medici, E.P., Desbiez, A.L.J., Gonçalves da Silva, A., Jerusalinsky, L., Chassot, O., Montenegro, O.L. et al. (eds) (2007) Workshop para a conservação da anta brasileira (Tapirus terrestris): Relatório final. IUCN/Species Survival Commission Tapir Specialist Group \& IUCN/Species Survival Commission Conservation Breeding Specialist Group, Sorocaba, Brazil.

Meritt, JR., D.A. (2006) Research questions on the behavior and ecology of the Giant Armadillo (Priodontes maximus). Edentata, 7, 30-33.

Michalski, F., Norris, D. \& Peres, C.A. (2010) No return from biodiversity loss. Science, 329, 1282.

Noss, A.J., Peña, R. \& Rumiz, D.I. (2004) Camera trapping Priodontes maximus in the dry forests of Santa Cruz, Bolivia. Endangered Species Update, 21, 43-52.

NowA , R.M. (1999) Walker's Mammals of the World. 6th edition. The Johns Hopkins University Press, Baltimore, USA.

Oliveira-Filho, A.T. \& Ratter, J.T. (2002) Vegetation physiognomies and woody flora of the cerrado biome. In The Cerrados of Brazil: Ecology and Natural History of a Neotropical Savanna (eds P.S. Oliveira \& R.J. Marquis), pp. 91-120. Columbia University Press, New York, USA.

Paul, J., Lewinsohn, T.M., Joly, C.A., Luciano, M., Martinelli, L.A. \& Rodrigues, R.R. (2010) Brazilian law: full speed in reverse? Science, 329, 276-277.

R Development Core Team (2014) R: A Language and Environment for Statistical Computing. R Foundation for Statistical 
Computing, Vienna, Austria. Https://www.r-project.org [accessed 20 July 2018].

Ribeiro, M.C., Metzger, J.P., Martensen, A.C., Ponzoni, F.J. \& Hirota, M.M. (2009) The Brazilian Atlantic Forest: how much is left, and how is the remaining forest distributed? Implications for conservation. Biological Conservation, 142, 1141-1153.

Rocha, E.C., Soares, K.L. \& Pereira, I.M. (2015) Medium and large-sized mammals in Mata Atlântica State Park, southeastern Goiás, Brazil. Check List, 11, 1-7.

Rushton, J., Viscarra, R., Viscarra, C., Basset, F., Baptista, R. \& BRown, D. (2005) How important is bushmeat consumption in South America: now and in the future? Wildlife Policy Briefing, 11, $1-4$.

Sanderson, E.W., Redford, K.H., Chetkiewicz, C.B., Medellin, R.A., Rabinowitz, A.R., Robinson, J.G. \& Taber, A.B. (2002) Planning to save a species : the jaguar as a model. Conservation Biology, 16, 58-72.

Silva, P.S.D., Leal, I.R., Wirth, R., Melo, F.P.L. \& Tabarelli, M. (2012) Leaf-cutting ants alter seedling assemblages across second-growth stands of Brazilian Atlantic forest. Journal of Tropical Ecology, 28, 361-368.

Silveira, L., Jácomo, A.T.A., Furtado, M.M., Torres, N.M., Sollmann, R. \& Vynne, C. (2009) Ecology of the giant armadillo
(Priodontes maximus) in the grasslands of central Brazil. Edentata, $8-10,25-34$.

Srbek-Araujo, A.C., Scoss, L.M., Hirsch, A. \& Chiarello, A.G. (2009) Records of the giant-armadillo Priodontes maximus (Cingulata: Dasypodidae) in the Atlantic Forest: are Minas Gerais and Espírito Santo the last strongholds of the species? Zoologia, 26, 461-468.

Superina, M. \& Abba, M. (2014) What do we know about armadillos? An analysis of four centuries of knowledge about a group of South American mammals, with emphasis on their conservation. Mammal Review, 44, 69-8o.

Terborgh, J., Lopez, L., Nuñez, P.V., Rao, M., Shahabuddin, G., Orihuela, G. et al. (2001) Ecological meltdown in predator-free forest fragments. Science, 294, 1923-1926.

van Vliet, N., Quiceno-Mesa, M.P., Cruz-Antia, D., De Aquino, L.J.N., Moreno, J. \& Nasi, R. (2014) The uncovered volumes of bushmeat commercialized in the Amazonian trifrontier between Colombia, Peru \& Brazil. Ethnobiology and Conservation, 3 , $1-11$.

Wetzel, R.M. (1985) The identification and distribution of recent Xenarthra. In The Evolution and Ecology of Armadillos, Sloths, and Vermilinguas (ed. G.G. Montgomery), pp. 5-21. Smithsonian Institution Press, Washington, DC, USA. 